\title{
Desiccation-Tolerant Rhizobacteria from Cholistan Desert, Pakistan, and Their Impact on Zea mays L.
}

\author{
Faiz Ahmad Raza, Aatif Amin, Muhammad Faisal* \\ Department of Microbiology and Molecular Genetics, University of the Punjab, \\ Quaid-e-Azam Campus, Lahore 54590, Pakistan
}

Received: 31 March 2014

Accepted: 8 July 2014

\begin{abstract}
Five desiccation-tolerant rhizobacteria (Brevibacterium frigoritolerans-LPS1B, Bacillus subtilisCHFT15, B. subtilis-CHFT12, B. subtilis-CH13, and Pseudomonas stutzeri-CHP413A) isolated from Pakistan's Cholistan desert were characterized on the basis of morphological, biochemical, and 16S rDNA ribotyping. The desiccation tolerance was checked at various relative humidity levels $(5,23$, and $100 \%)$ for a period of 1-40 days. Heavy metal and antibiotic resistance, auxin, cytokine, siderophore, hydrogen cyanide production, and phosphate solubilization of select bacterial isolates was also investigated. Pot experiments with corn in sandy and pure soil were also carried out to check the plant growth-promoting potential of select strains after 90 days of growth. After harvest, various growth parameters like seed germination, root and shoot length, number of leaves, dry weight per gram fresh weight, and chlorophyll contents were determined. The inoculation of P. stutzeri-CHP413A resulted in 3, 33,12, and 37\% increases in seed germination, number of leaves, shoot and root length, and dry weight $\cdot \mathrm{g}^{-1}$ fresh weight, respectively, in sandy soil $(\mathrm{p}<0.05)$.
\end{abstract}

Keywords: desiccation, bacteria, exopolysaccharide, phytohormones, Zea mays

\section{Introduction}

Abiotic stresses affect the microbial community in soil, resulting in the loss in productivity of agricultural crops [1]. The environmental factors include scarcity of food, drought, salinity, flooding, temperatures, and $\mathrm{pH}[2,3]$. Rhizospheric microbial communities possess physiological flexibility to a particular environmental factor by changing the composition and biomass of community [4].

Plant growth-promoting rhizobacteria (PGPR) live in the rhizospheric soil and have an association with roots of various plants either directly or indirectly for enhancing the growth and development of plants [5]. PGPR strains possess various properties, like exopolysaccharide production

*e-mail: mohdfaysal@yahoo.com
[6] and enzyme ACC deaminase [7], to cope with a variety of abiotic and biotic stresses [8] such as salt stress [9], flooding stress [10], drought stress [11], heavy metal stress [12], and pathogen attack [13]. Desiccation is one of the major problems in the agriculture sector causing limited crop yield in most of the arid and semiarid zones worldwide [14]. This form of abiotic stress causes specific and nonspecific reactions, and damage at sub-cellular, cellular, and whole plant level with respect to plant water relation [15].

Generally, microorganisms live within the envelope of the exopolysaccharide (EPS) matrix in many environments like soils, lungs, etc. However, the most frequently discussed possibility is that an EPS envelope matrix protects bacteria from drought by enhancing water retention and from fluctuations in water potential by regulating the diffusion of organic carbon sources [16]. EPS also helps the bac- 
teria in colonization with the plant roots due to fibrous network material that connects the bacteria to the root surface [17]. Inoculation of maize plants (Zea mays L.) with desiccation-tolerant indole acetic acid (IAA) producing beneficial bacteria increased drought tolerance of plants growing in arid as well as semiarid areas [18, 19].

Therefore, the present study was an attempt to isolate and characterize exopolysaccharide (EPS) and indole acetic acid (IAA)-producing desiccation-tolerant bacteria from Cholistan desert, a natural habitat that provided the best benefit for desiccation-stressed plants.

\section{Materials and Methods}

\section{Sample Collection and Bacterial Isolation}

Different soil and plant samples were collected from the Cholistan desert and Multan Bypass, Pakistan. Samples were collected in tightly packed plastic bags and transferred to the laboratory, where they were kept at room temperature. The $\mathrm{pH}$ and moisture content was determined for each sample. For isolation of single bacterial colonies, tenfold dilution was prepared for each $1 \%$ sample, and $100 \mu \mathrm{l}$ from each dilution was spread on modified Trypticase glucose yeast (mTGY) agar plates containing $5 \mathrm{~g}$ casein peptone, $1 \mathrm{~g}$ glucose, $2.5 \mathrm{~g}$ yeast extract, and $15 \mathrm{~g}$ agar in $1000 \mathrm{ml}$ distilled water. The $\mathrm{pH}$ was adjusted between 7.2 to 7.5. After $24 \mathrm{~h}$ of incubation at $37^{\circ} \mathrm{C}$, the growth of the different colonies was obtained. Single colonies were selected and streaked on new mTGY agar plates. The plates were incubated in the same conditions as before to get pure single colonies. Single pure colonies were preserved as 30\% glycerol stocks at $-80^{\circ} \mathrm{C}$ for further use in experiments.

\section{Characterization of Bacterial Isolates}

Select bacterial isolates were morphologically and biochemically characterized by Gram stain, spore stain, capsule stain, catalase, oxidase, citrate utilization, urease, starch hydrolysis, nitrate reduction, denitrification, sulfideindole-motility (SIM), gelatin liquefaction, VogesProskauer, $\mathrm{H}_{2} \mathrm{~S}$ production, and methyl red. The select bacterial isolates showing promising results (LPS1B, CHFT15, CHFT12, CH13, and CHP413A) were grown in LB broth at $37^{\circ} \mathrm{C}$ overnight and were processed for DNA extraction using the modified CTAB method as described by Shahzadi et al. [20]. Amplification of part of 16S rDNA was performed using universal primers 16S-F (5'AAACTCAAATGAATTGACGG3') and 16S-R (5'TCCTCCGCTTATTGATATGC3'). Amplification conditions using a BIOER XP-Thermal Cycler were: $95^{\circ} \mathrm{C}(5 \mathrm{~min}), 35$ cycles of $95^{\circ} \mathrm{C}(1 \mathrm{~min}), 55^{\circ} \mathrm{C}(1 \mathrm{~min})$, and $72^{\circ} \mathrm{C}(2 \mathrm{~min})$, with a final 5 min chain elongation at $72^{\circ} \mathrm{C}$.

\section{Screening of Desiccation-Tolerant Bacteria}

Select bacterial isolates were grown in $50 \mathrm{ml} \mathrm{LB}$ broth at $37^{\circ} \mathrm{C}$ while shaking at $150 \times \mathrm{g}$. After $24 \mathrm{~h}$ of incubation, the culture was centrifuged at $10,000 \times \mathrm{g}$ for $5 \mathrm{~min}$. Cell pellet was suspended in phosphate-buffered saline (PBS) and optical density (OD) of each culture was adjusted to 0.5 at $600 \mathrm{~nm}$. Aliquot of $25 \mu \mathrm{l}$ culture was transferred to a prewashed, sterile glass slide $(25 \times 37.5 \mathrm{~mm})$ and evenly distributed using the tip of another glass slide. Glass slides were left to dry at room temperature (R.H. 33\%) for $6 \mathrm{~h}$. A total of 27 slides for each isolate were prepared and placed vertically on the perforated plates (made up of thermo pore packing material) in three different glass desiccators.

The relative humidity of the desiccators was controlled by filling their bases with silica gel (R.H. 5\%) or sterile saturated solution of potassium acetate (R.H. 23\%) or sterile distilled water (R.H. 100\%). Desiccators were placed in a sterile incubator at $37^{\circ} \mathrm{C}$. The survival rate of each isolate, under desiccated state, was calculated by growing bacteria on LB agar up to one month. After every five days, cells deposited over glass slides were re-suspended by adding $100 \mu \mathrm{l}$ of sterile saline water $(0.9 \%)$ and rubbing it with a micropipette tip. This suspension was transferred to $10 \mathrm{ml}$ saline water and mixed well. The process was repeated four times to confirm that all cells on the slide were re-suspended. Suspension was further serial. The number of colonyforming units (CFUs) was determined by incubating plates at $37^{\circ} \mathrm{C}$ for $24 \mathrm{~h}$.

\section{Cross-Metal Resistance and Antibiotic Susceptibility}

Heavy metal tolerance in these isolates was checked by preparing stock solutions of different metal salts such as arsenic pentoxide $\left(500 \mu \mathrm{g} \cdot \mathrm{ml}^{-1}\right)$, arsenic trioxide (200 $\left.\mu \mathrm{g} \cdot \mathrm{ml}^{-1}\right)$, cadmium chloride $\left(100 \mu \mathrm{g} \cdot \mathrm{ml}^{-1}\right)$, copper sulphate $\left(100 \mu \mathrm{g} \cdot \mathrm{ml}^{-1}\right)$, and potassium chromate $\left(500 \mu \mathrm{g} \cdot \mathrm{ml}^{-1}\right)$. The metal tolerance profile was recorded by gradually increasing the concentration of various heavy metals in a stepwise manner with $50 \mu \mathrm{g} \cdot \mathrm{ml}^{-1}$ of metal increased each time. The plates supplemented with various heavy metals were incubated at $37^{\circ} \mathrm{C}$ overnight. The antibiotic susceptibility of select bacterial isolates was checked by measuring the zone of inhibition against antibiotics, chloramphenicol (30 $\left.\mu \mathrm{g} \cdot \mathrm{ml}^{-1}\right)$, streptomycin $\left(10 \mu \mathrm{g} \cdot \mathrm{ml}^{-1}\right)$, kanamycin (30 $\left.\mu \mathrm{g} \cdot \mathrm{ml}^{-1}\right)$, oxytetracyclin $\left(30 \mu \mathrm{g} \cdot \mathrm{ml}^{-1}\right)$, ampicillin $\left(10 \mu \mathrm{g} \cdot \mathrm{ml}^{-1}\right)$, and erythromycin $\left(15 \mu \mathrm{g} \cdot \mathrm{ml}^{-1}\right)$.

\section{Screening for Plant Growth-Promoting Traits}

\section{Cytokinin Production}

To check cytokinin production by the select axenic bacterial isolates, a modified cucumber cotyledon greening bioassay was used. Bacterial cultures were streaked on half sides of the M9 medium containing $20 \%$ glucose, $0.2 \%$ casamino acid, $2 \mathrm{pg} / \mathrm{l}$ biotin, and $0.7 \%$ agar for $72 \mathrm{~h}$, and then the etiolated cotyledons from five-day-old cucumber seedlings were placed on the other half by avoiding direct contact [21]. After $24 \mathrm{~h}$ of incubation at $25^{\circ} \mathrm{C}$ in the dark, the plates were exposed to light $\left(55 \mu \mathrm{mol} \cdot \mathrm{m}^{-2} \cdot \mathrm{s}^{-1}\right)$ for three $\mathrm{h}$ at room temperature. Chlorophyll content of the cotyledons 
relative to negative control (bacterial culture's lack of ability to produce cytokinin) was measured by a UV 4000 spectrophotometer, O.R.I. (Germany). Benzyl amino purine (BAP) of $10 \mu \mathrm{M}$ concentration was taken as positive control. Increased chlorophyll content provides evidence for positive cytokinin activity. The experiment was done thrice with each bacterial culture.

\section{Auxin Synthesis}

Auxin estimation was carried out by following the method of Tang and Borner [22]. Briefly, $5 \mathrm{ml}$ tryptone water was inoculated with bacterial isolates and incubated at $37^{\circ} \mathrm{C}$ for $24 \mathrm{~h}$. After incubation, 2-3 drops of orthophosphoric acid and $2 \mathrm{ml}$ of Salkowski reagent (4.5 $\mathrm{g} \mathrm{of} \mathrm{FeCl}_{3}$ per liter in $10.8 \mathrm{M} \mathrm{H}_{2} \mathrm{SO}_{4}$ ) were added to $1 \mathrm{ml}$ supernatant, and after $30 \mathrm{~min}$ of incubation at room temperature, the color development from yellow to pinkish was monitored at $600 \mathrm{~nm}$ by a UV 4000 spectrophotometer.

\section{Phosphate Solubilization}

Bacterial isolates were stabbed by sterile toothpick on Pikovskaya medium $\left(\mathrm{g} \cdot \mathrm{ml}^{-1}\right)$ containing glucose 10 , yeast extract 0.5, $\left(\mathrm{NH}_{4}\right)_{2} \mathrm{SO}_{4} 0.5, \mathrm{MgSO}_{4} \cdot 7 \mathrm{H}_{2} \mathrm{O} 0.1, \mathrm{Ca}_{3}\left(\mathrm{PO}_{4}\right)_{2} 5$, $\mathrm{NaCl} 0.2, \mathrm{KCl} 0.2, \mathrm{MnSO}_{4} \cdot 2 \mathrm{H}_{2} \mathrm{O} 0.002, \mathrm{FeSO}_{4} \cdot 7 \mathrm{H}_{2} \mathrm{O}$ 0.002 , and agar 1.5 , and plates were incubated at $25^{\circ} \mathrm{C}$ for 4-5 days. Transparent zone of clearing around the colonies of bacterial cultures indicated that phosphate has been solubilized in the clearing zone.

\section{Hydrogen Cyanide Production}

Bacterial isolates were screened for the production of hydrogen cyanide $(\mathrm{HCN})$ by adapting the method of Lorck [23] described by Ahmed et al. [24]. Bacteria were streaked on $\mathrm{N}$-agar plate, and a filter paper soaked in $0.5 \%$ picric acid solution was placed on the top of the agar surface. Plates were incubated at $30^{\circ} \mathrm{C}$ for 4 days. Development of orange to red color indicated HCN production.

\section{Siderophore Production}

Siderophore production was checked by the method of Louden et al. [25]. Select bacterial strains were streaked on the plates of Chrome Azurol-S (CAS) medium. Yellow colored colonies of bacterial strains indicated siderophore production.

\section{Selection of EPS Producers}

EPS-producing isolates were selected on the basis of their highly mucoid growth on the solid medium and positive string test. Microscopic examination confirmed the production of extracellular polysaccharide. For microscopy, bacterial cells were fixed on a glass slide with $3 \%$ acetic acid for $30 \mathrm{~min}$ and then stained with Alcian Blue 8GX in $3 \%$ acetic acid. Finally, extra stain was removed by washing with distilled water and slides were viewed under a compound microscope.

\section{Quantitative Estimation of EPS}

Select bacterial isolates were grown in N-broth at $37^{\circ} \mathrm{C}$ for $72 \mathrm{~h}$ with constant stirring at $150 \times \mathrm{g}$. After $72 \mathrm{~h}$ of incubation, cell-free extract of each isolate was prepared by centrifuging at $16,000 \times \mathrm{g}$ for $15 \mathrm{~min}$ at $4^{\circ} \mathrm{C}$ and then filtered through $0.2 \mu \mathrm{m}$ filter paper using a filter assembly attached to a vacuum pump. Polysaccharides were precipitated out by mixing $1: 3$ volumes of extract and cold acetone and kept for $24 \mathrm{~h}$ at $-20^{\circ} \mathrm{C}$. Precipitate was separated by centrifuging at $16,000 \mathrm{~g}$ for $15 \mathrm{~min}$ at $4^{\circ} \mathrm{C}$ and re-suspended in water. The suspension was lyophilized and stored at $-20^{\circ} \mathrm{C}$. Quantitative estimation EPS was determined by the Phenol/Sulfuric acid essay described by DuBois et al. [26]. According to this assay, $0.5 \mathrm{ml}$ sugar solution was mixed with $0.25 \mathrm{ml}$ of $5 \%$ aqueous solution of phenol, and $1.5 \mathrm{ml}$ $\mathrm{H}_{2} \mathrm{SO}_{4}$ (conc.) was added immediately to the mixture. The samples were allowed to stand for $10 \mathrm{~min}$, vortexes for $1 \mathrm{~min}$ and kept for 10 to $20 \mathrm{~min}$ in water bath at $25^{\circ} \mathrm{C}$ to $30^{\circ} \mathrm{C}$. Absorbance of each sample was measured at $490 \mathrm{~nm}$ by UV spectrophotometer. Blank control was prepared by substituting sugar aliquot with DDI. The concentration of extracellular polysaccharide was determined with reference to standard curve of glucose solution.

\section{Fermentation Optimization for EPS}

\section{Media Optimization}

To investigate the effects of various media on EPS production by select bacterial isolates, four different growth media, including Luria Bertani (LB) broth, tryptic soya broth (TSB), EPS selective medium [27], and Pharma media were used. Bacterial cultures were inoculated in TSB medium for making $500 \mu \mathrm{L}$ as a starter culture and incubated at $37^{\circ} \mathrm{C}$ for $24 \mathrm{~h}$ at $150 \times \mathrm{g}$. Each bacterial culture was introduced into four different growth media having cell number approximately to $10^{7}$ cells $\cdot \mathrm{ml}^{-1}$ and re-incubated at $37^{\circ} \mathrm{C}$ for $48 \mathrm{~h}$ with shaking at $150 \times \mathrm{g}$. The growth was monitored spectrophotometrically at $600 \mathrm{~nm}$, while EPS production was estimated after acetone precipitation.

\section{Temperature Optimization}

For the preparation of inoculum, bacterial isolates were grown for $24 \mathrm{~h}$ in $\mathrm{TSB}$ at $37^{\circ} \mathrm{C}$ while shaking at $150 \times \mathrm{g}$. The number of bacterial cells was adjusted approximately to $10^{7}$ cells $\cdot \mathrm{ml}^{-1}$ and $500 \mu \mathrm{l}$ was introduced into EPS medium. After the inoculation of starter culture, flasks were incubated in the range of $25^{\circ} \mathrm{C}$ to $42^{\circ} \mathrm{C}$ for $48 \mathrm{~h}$ with shaking at $150 \times \mathrm{g}$. The growth of each bacterial isolate was monitored at $600 \mathrm{~nm}$ and EPS production was estimated after acetone precipitation.

\section{pH Optimization}

To check the increase in bacterial cell number and EPS production, $500 \mu \mathrm{l}$ starter culture of each bacterial isolate having $10^{7}$ cells $\cdot \mathrm{ml}^{-1}$ after $24 \mathrm{~h}$ of incubation at $37^{\circ} \mathrm{C}$ was 
inoculated into EPS medium. All the flasks were incubated at $\mathrm{pH} 6$ to 10 for $48 \mathrm{~h}$ with shaking at $150 \times \mathrm{g}$ and growth and EPS production were determined.

\section{Plant Growth Experiments in the Field}

Plant growth-promoting ability of selected bacterial isolates was checked with maize (Zea mays). Maize seeds were surface sterilized in $0.2 \%$ mercuric chloride $\left(\mathrm{HgCl}_{2}\right)$ for $10 \mathrm{~min}$ and then washed thrice with sterile distilled water to remove any traces of $\mathrm{HgCl}_{2}$ from the seeds. The surface-sterilized seeds were transferred to bacterial cell suspensions having bacterial cell density of approximately $10^{7}$ cells $\cdot \mathrm{ml}^{-1}$ for $1 \mathrm{~h}$, while control seeds were soaked in sterile distilled water for the same time period. After seed bacterization, 12 seeds were sown into each pot containing $3 \mathrm{~kg}$ of mixture of sand and soil (1:1) or field soil alone. Two replicates were also included for each bacterially treated and untreated seed groups. Pots were watered equally on a daily basis up to one month. Afterward, pots were watered twice a day up to maturation of plants. Germination of seeds was recorded after two weeks and percentage germination was calculated from the data. Thinning of the plants was carried out after one month and only seven plants were left to grow in each pot. Plants were harvested after maturation and they were monitored for root length, shoot length, fresh mass, dry mass, and chlorophyll content in each type of treated and control plant.

\section{Statistical Analysis}

All the data were tested statistically by analysis of variance (ANOVA) using SPSS + Version 20. Each treatment in pot experiment with maize was analyzed with five replicates and a standard deviation (SD) was calculated. The data expressed are mean $\pm \mathrm{SD}$ of each replicate, then means were compared by Duncan's multiple range test.

\section{Results}

\section{Isolation and Purification of Bacterial Isolates}

Samples collected from Cholistan desert and Multan Bypass were spread on LB plates and incubated at $37^{\circ} \mathrm{C}$. After $24 \mathrm{~h}$, single colonies were picked and streaked on the same medium plates. A total of 200 bacterial isolates were isolated and five were selected for their ability to produce highly mucoid colonies on agar medium and form a long string when picked up with inoculating loop. Blue mucosubstance due to Alcian blue staining of the selected isolates revealed their potential to produce EPS.

\section{Strains Characterization}

All the selected isolates were morphologically and biochemically identified using a compound microscope and different biochemical tests. The morphological features of
Table 1. Morphological and biochemical tests for the selected isolates.

\begin{tabular}{|c|c|c|c|c|c|}
\hline Bacterial isolate & 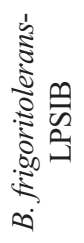 & 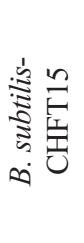 & 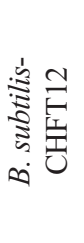 & 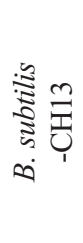 & 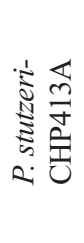 \\
\hline Shape & Rods & Rods & Rods & Rods & Rods \\
\hline Motility & + & + & + & + & + \\
\hline Gram reaction & + & + & + & + & + \\
\hline Spore formation & - & + & + & + & - \\
\hline Capsule formation & + & + & + & + & + \\
\hline Catalase & + & + & + & + & + \\
\hline Oxidase & + & + & + & + & - \\
\hline Urease & - & - & - & - & - \\
\hline Indole & - & - & - & - & - \\
\hline Oxidation & + & + & + & + & + \\
\hline Fermentation & + & + & + & + & + \\
\hline MRVP & - & - & - & - & - \\
\hline Nitrate reduction & - & + & + & + & + \\
\hline Denitrification & + & + & + & + & + \\
\hline Citrate utilization & - & - & + & + & - \\
\hline Starch hydrolysis & + & + & + & + & + \\
\hline Gelatin liquefaction & - & + & + & + & + \\
\hline $\mathrm{H}_{2} \mathrm{~S}$ production & - & - & - & - & - \\
\hline
\end{tabular}

bacterial isolates were circular, entire, convex, smooth, viscous, and opaque. All the isolates showed Gram-positive chains of rods as a result of Gram staining, capsule forming, and motile under compound microscope, and gave biochemically positive results of catalase, oxidation, fermentation, denitrification, and starch hydrolysis (Table 1). Then those bacterial isolates showed high tolerance against desiccation by producing EPS and giving promising results with respect to plant-promoting activities (LPS1B, CHFT15, CHFT12, CH13, and CHP413A) characterized through 16S rDNA sequencing. The sequences of strains LPS1B, CHFT15, CHFT12, CH13, and CHP413A were blasted on NCBI and obtained closest homology with Brevibacterium frigoritolerans, Bacillus subtilis, Bacillus subtilis, Bacillus subtilis, and Pseudomonas stutzeri, respectively.

\section{Survival Rate of Bacteria Desiccated in PBS}

The survival rate of select bacterial strains $B$. frigoritolerans-LPS1B, B. subtilis-CHFT15, B. subtilis-CHFT12, B. subtilis-CH13, and P. stutzeri-CHP413A in response to 
desiccation at 5, 23, and 100\% relative humidity under constant pressure was monitored by plate count method following incubation at different time intervals ranging 1-40 days. B. frigoritolerans-LPS1B showed a higher survival rate at the beginning of the desiccation period at higher humidity levels (R.H. 23\% and 100\%) as compared to a drastic decrease in cell numbers at R.H. 5\%. In contrast to all other isolates, $P$. stutzeri-CHP413A showed a varying trend by surviving at all humidity levels (5, 23 and 100\%) except at the end of the incubation period. It showed high endurance at lower R.H. (R.H. 5\%) in contrast to higher humidity levels (R.H. 23\% and 100\%) (Fig. 1).

\section{Cross Metal and Antibiotic Resistance}

All the isolates were sensitive to given concentrations of cadmium $\left(\mathrm{Cd}^{+2}\right)$ and copper $\left(\mathrm{Co}^{+2}\right)$. B. subtilis-CHFT15, B. subtilis-CHFT12, B. subtilis-CH13, and P. stutzeriCHP413A were found resistant to arsenate $\mathrm{As}^{+5}$ at 500 $\mu \mathrm{g} / \mathrm{ml}$, while $P$. stutzeri-CHP413A was also resistant to arsenite $\left(\mathrm{As}^{+3}\right)$. Moreover, B. subtilis-CHFT12, B. subtilis$\mathrm{CH} 13$, and $P$. stutzeri-CHP413A were able to tolerate $\mathrm{Cr}^{+6}$ at $500 \mu \mathrm{g} \cdot \mathrm{ml}^{-1}$. All the selected bacterial strains were sensitive to the given concentration of oxy-tetracycline (Tc), kanamycin $(\mathrm{Kn})$, streptomycin (Sm), and erythromycin (E) while resistant to chloramphenicol $(\mathrm{Cm})$. P. stutzeriCHP413A was found to be resistant to chloramphenicol (Cm) as well as ampicillin (Ap) (Table 2).

\section{Plant Growth Promoting Activities of Bacteria}

All the selected bacterial isolates were screened for various plant growth-promoting traits (cytokinin, siderophores, HCN, phosphate solubilization) before the field trial experiments. The results of the present study showed that among phytohormones, the strains of $B$. frigoritolerans-LPS1B, B. subtilis-CHFT15, B. subtilisCHFT12, B. subtilis-CH13, and P. stutzeri-CHP413A were able to produce cytokinin, while in the case of indole acetic acid production they showed negative results. Like IAA production, all the strains were also unable to produce siderophores and failed to solubilize inorganic phosphates.
Table 2. Heavy metal and antibiotic resistance in select isolates.

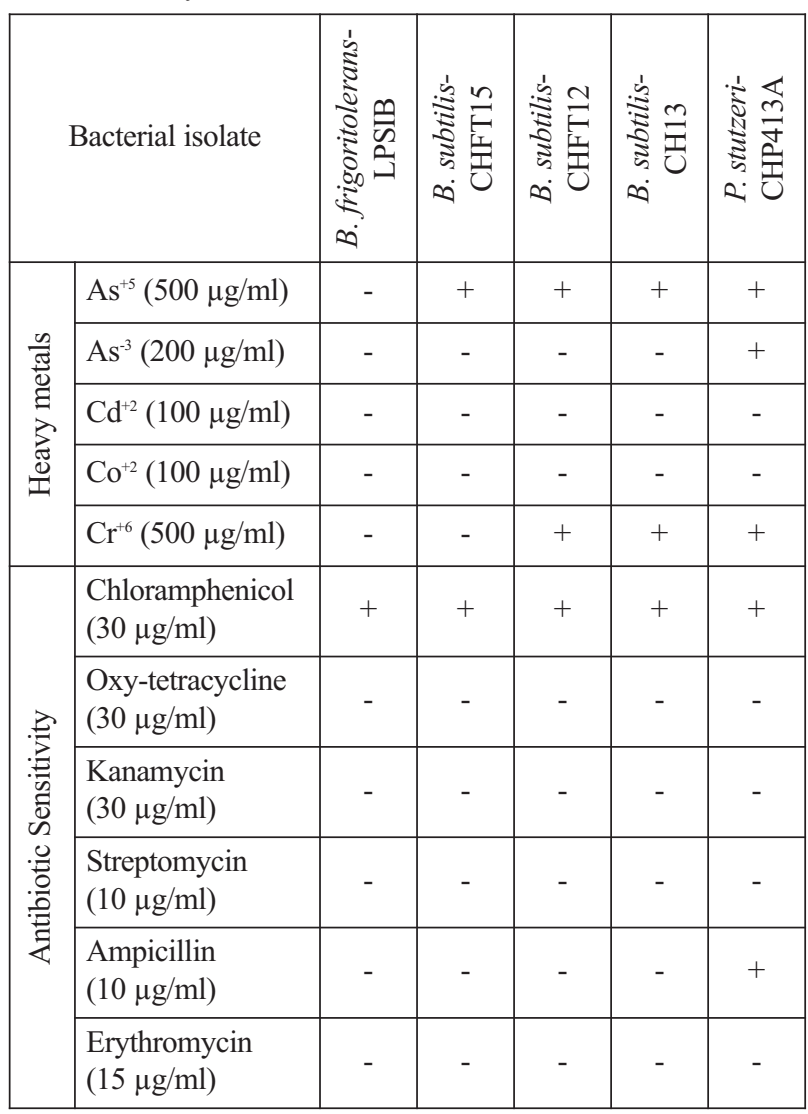

Moreover, P. stutzeri-CHP413A showed maximum potential to produce $\mathrm{HCN}$, while $B$. subtilis-CH13 gave negative results in the case of $\mathrm{HCN}$ production (Table 3 ).

\section{Optimization of Fermentation Conditions for EPS Production}

\section{Growth Media, pH, and Temperature}

Microorganisms need nutrients as their energy source; optimum $\mathrm{pH}$ and temperature in order to grow and reproduce were optimized. Five different growth media - LB a)

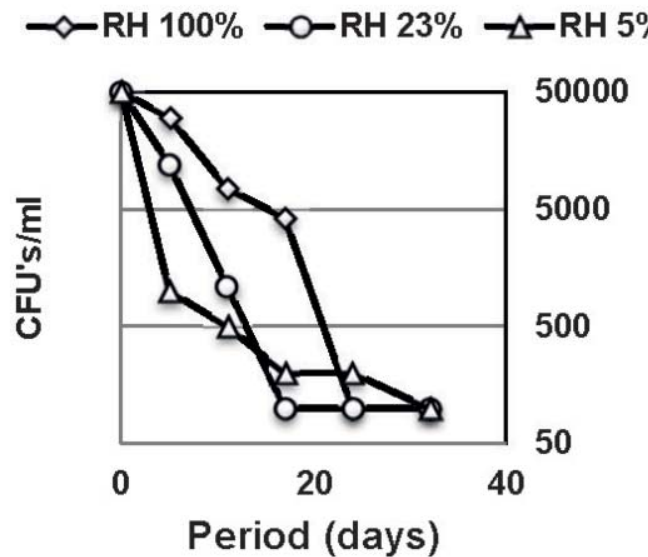

b)

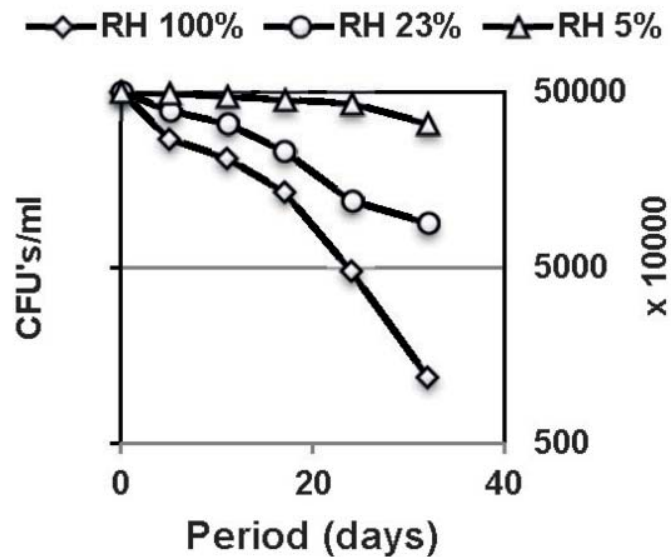

Fig. 1. Survival rates of B. frigoritolerans-LPS1B (a) and P. stutzeri-CHP413A (b) at various humanities (5, 23, and 100\%) for a period of 1-40 days. 
Table 3. Screening for multiple plant growth-promoting activities of select bacteria.

\begin{tabular}{|l|c|c|c|c|c|}
\hline \multirow{2}{*}{ Bacterial isolate } & \multicolumn{2}{|c|}{ Phytohormones } & \multirow{2}{*}{$\begin{array}{c}\text { Phosphate } \\
\text { solubilization }\end{array}$} & Hydrogen Cyanide & $\begin{array}{c}\text { Siderophore } \\
\text { production }\end{array}$ \\
\cline { 2 - 5 } & IAA & Cytokinin & - & ++ & - \\
\hline B. frigoritolerans-LPS1B & - & + & - & ++ & - \\
\hline B. subtilis-CHFT15 & - & + & - & ++ \\
\hline B. subtilis-CHFT12 & - & + & - & - & - \\
\hline B. subtilis-CH13 & - & + & - & +++ & + \\
\hline P. stutzeri-CHP413A & - & + & & + \\
\hline
\end{tabular}

broth, TSB, EPS medium, and Pharmamedia at various $\mathrm{pH}$ $(6,7,8,9$, and 10$)$ and temperatures $\left(25^{\circ} \mathrm{C}, 30^{\circ} \mathrm{C}, 37^{\circ} \mathrm{C}\right.$, $42^{\circ} \mathrm{C}$, and $46^{\circ} \mathrm{C}$ ) - were tested for their ability to enhance EPS production by the select isolates. After $72 \mathrm{~h}$ of incubation, the maximum growth of all isolates was observed in Pharmamedia and maximum EPS yield was observed in TSB medium at optimum temperature of $37^{\circ} \mathrm{C}$ and neutral $\mathrm{pH}$ of 7 (Fig. 2).

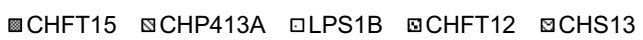

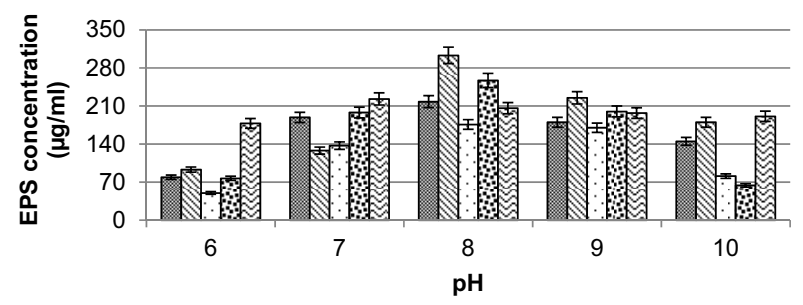

口LPS1B MCHFT15 \&CHP413A 日CHFT12 日CHS13

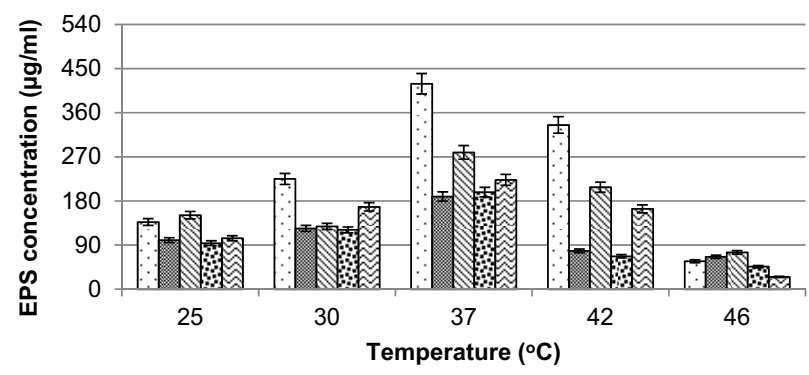

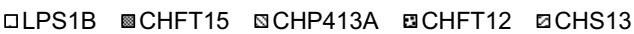

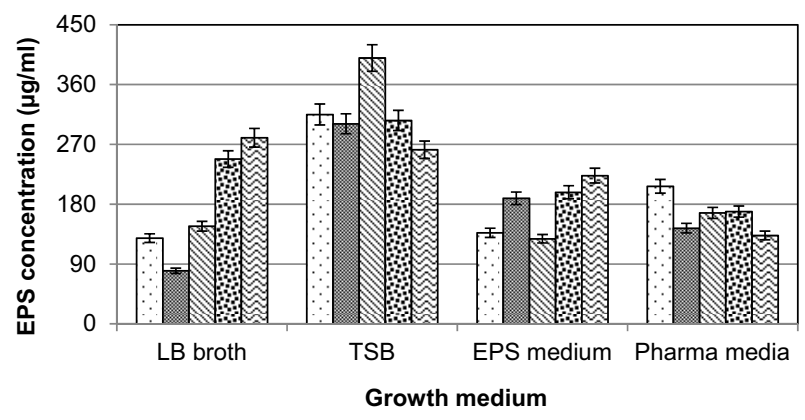

Fig. 2. Impact of $\mathrm{pH}$, temperature, and various growth media on exopolysaccharide production by bacterial strains incubated at $37^{\circ} \mathrm{C}$ for $72 \mathrm{~h}$ at $150 \times \mathrm{g}$.

\section{EPS Extraction}

Isolation and purification of EPS was accomplished by precipitation with acetone followed by lyophilization of all select bacterial isolates. Maximum dry weight of EPS yielded $2.5 \mathrm{~g}$ and protein concentration was estimated $0.888 \mathrm{mg} / 10 \mathrm{mg}$ of EPS in the case of P. stutzeriCHP413A, while $0.5 \mathrm{~g}$ dry weight of EPS and $0.83 \mathrm{mg} / 10$ $\mathrm{mg}$ of EPS protein concentration for B. frigoritoleransLPS1B, $0.7 \mathrm{~g}$ dry weight of EPS, and $0.8 \mathrm{mg} / 10 \mathrm{mg}$ of EPS protein concentration for $B$. subtilis-CHFT15 and B. subtilis-CHFT12, and $0.4 \mathrm{~g}$ dry weight of EPS and $0.7 \mathrm{mg} / 10$ $\mathrm{mg}$ of EPS protein concentration were estimated for $B$. subtilis-CH13 (Fig. 3).

\section{Plant Growth Promotion by Desiccation-Tolerant Bacteria}

The plant growth-promoting ability of desiccation-tolerant bacterial isolates was checked with Zea mays; both in pure soil as well as in mixed soil (Table 4, Fig. 4). Bacterial inoculation had seemed to have significant impact on a number of leaves in mixed soil as compared to uninoculated seeds. The same growth-promoting effect was observed for shoot length and root length as compared to control plants as given in Table 3. The inoculation of $P$. stutzeri-CHP413A resulted in $6,18,23,37$, and $100 \%$ increases in germination, number of leaves, shoot and root length, and dry weight $\mathrm{g}^{-1}$ fresh weight in pure soil, and 3,33,12,37, and $0 \%$ increases in above-mentioned plant growth parameters for sandy soil $(p<0.05)$. In contrast, numbers of leaves in pure soil were increased as compared to mixed soil and control plants.

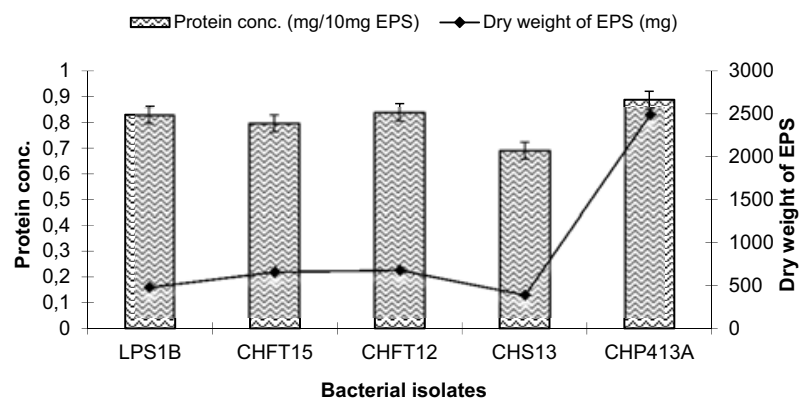

Fig. 3. Dry weight of EPS and protein concentrations in EPS of bacterial strains. 
Table 4. Effect of five bacterial inoculations on seed germination, number of leaves, shoot length, root length, and dry weight per gram fresh weight of Zea mays grown in pure and mixed soil.

\begin{tabular}{|c|c|c|c|c|c|c|}
\hline Soil type & Treatment & $\begin{array}{c}\text { Germination } \\
(\%)\end{array}$ & $\begin{array}{l}\text { Number } \\
\text { of leaves }\end{array}$ & $\begin{array}{l}\text { Shoot length } \\
(\mathrm{cm})\end{array}$ & $\begin{array}{l}\text { Root length } \\
(\mathrm{cm})\end{array}$ & $\begin{array}{l}\text { Dry weight } \cdot g^{-1} \\
\text { fresh weight }(g)\end{array}$ \\
\hline \multirow{6}{*}{ Pure soil } & Control & $94.4+0.3$ (a) & $11.0+1.0(\mathrm{a})$ & $59.6+3.2$ (a) & $33.6+3.6$ (a) & $0.1+0.1$ (a) \\
\hline & LPS1B & $94.4+0.3$ (a) & $13.0+0.8(\mathrm{c})$ & $68.6+3.7$ (b) & $46.4+2.9$ (e) & $0.2+0.1(b)$ \\
\hline & CHFT15 & $94.4+0.3$ (a) & $13.0+0.7$ (c) & $72.0+3.4(\mathrm{~d})$ & $41.9+3.4(\mathrm{c})$ & $0.2+0.1(b)$ \\
\hline & CHFT12 & $100+0.1(\mathrm{c})$ & $12.0+1.3(\mathrm{~b})$ & $70.9+3.7(\mathrm{c})$ & $40.7+3.2(b)$ & $0.2+0.08(b)$ \\
\hline & $\mathrm{CH} 13$ & $97.2+0.3$ (b) & $13.0+1.0(\mathrm{c})$ & $72.6+3.2(\mathrm{~d})$ & $43.1+3.7(d)$ & $0.2+0.2$ (b) \\
\hline & CHP413A & $100+0.3(\mathrm{c})$ & $13+1.1(\mathrm{c})$ & $73.0+3.5(\mathrm{e})$ & $46.1+3.5(\mathrm{e})$ & $0.2+0.2(b)$ \\
\hline \multirow{6}{*}{ Mixed soil } & Control & $100+0.2(d)$ & $9.0+1.4(\mathrm{a})$ & $56.0+3.5$ (a) & $35.3+3.7$ (a) & $0.2+0.1$ (b) \\
\hline & LPS1B & $94.4+0.3$ (b) & $11.0+0.7$ (b) & $68.9+3.4(\mathrm{~d})$ & $51.4+2.6(\mathrm{f})$ & $0.2+0.1(b)$ \\
\hline & CHFT15 & $97.2+0.3(\mathrm{c})$ & $12.0+0.8(\mathrm{c})$ & $69.0+3.1(\mathrm{e})$ & $49.6+3.9(\mathrm{e})$ & $0.18+0.09$ (a) \\
\hline & CHFT12 & $91.6 \pm 0.2$ (a) & $13.0+0.8(\mathrm{~d})$ & $62.9+3.0(\mathrm{~b})$ & $42.3+3.5(b)$ & $0.18+0.09$ (a) \\
\hline & $\mathrm{CH} 13$ & $94.4+0.3$ (b) & $13.0+1.0(\mathrm{~d})$ & $66.6+3.0(\mathrm{c})$ & $43.3+2.9(\mathrm{c})$ & $0.2+0.1(b)$ \\
\hline & CHP413A & $97.2+0.3(\mathrm{c})$ & $12.0+1.1(\mathrm{c})$ & $62.9+3.1(\mathrm{~b})$ & $48.6+2.6(\mathrm{~d})$ & $0.2+0.1$ (b) \\
\hline
\end{tabular}

The results shown are means of three independent experiments \pm standard error.

The $\mathrm{p}<0.05$ was calculated by ANOVA, and different letters indicate significant differences between means of each treatments calculated by Duncan's multiple range test $(\mathrm{P}=0.05)$.

\section{Discussion}

Microorganisms, especially bacteria, help crop plants to increase their tolerance and adaptation to abiotic stresses. In the present investigation, the isolated strains belong to different genera like Brevibacterium, Bacillus, and Pseudomonas; the first two are desiccation-tolerant grampositive aerobic bacteria, while the third is a desiccationtolerant gram-negative aerobic rod-shaped bacterium.

Results of desiccation tolerance showed that strain B. frigoritolerans-LPS1B showed higher survival rate at

\section{$\square \mathrm{Ca}$ 国 $\mathrm{Cb}$ 吕x+C}

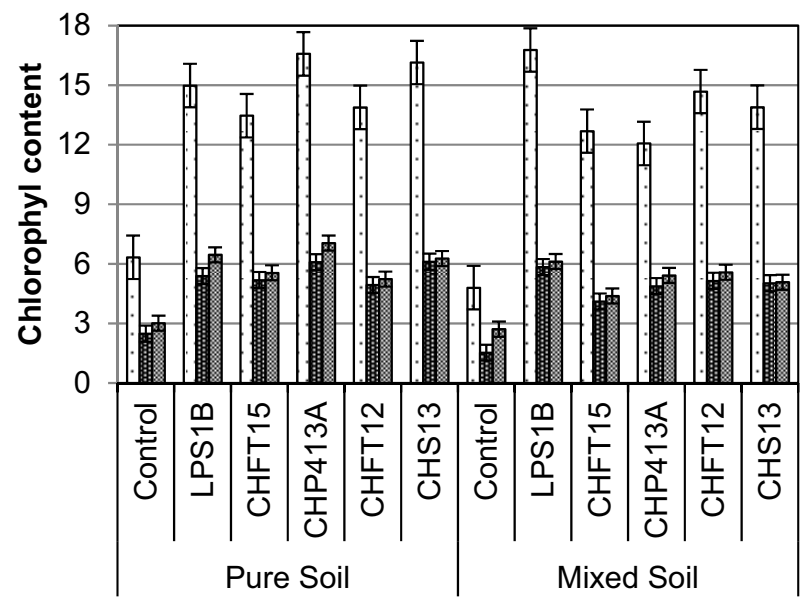

Fig. 4. Effect of bacterial inoculation on chlorophyll $a, b$, and carotenoid content of 30-day-old Zea mays plants. Ca - chlorophyll $a, \mathrm{Cb}-$ chlorophyll $b$, and $\mathrm{Cx}+\mathrm{c}-$ carotenoids. Bars represent mean $\pm \mathrm{SE}$. the beginning of the desiccation period at higher humidity levels (R.H. 23\% and 100\%) as compared to a drastic decrease in cell numbers at R.H. 5\%. Strains B. subtilisCHFT15, B. subtilis-CHFT12, B. subtilis-CH13, and P. stutzeri-CHP413A were found resistant to arsenate $\mathrm{As}^{+5}$ at $500 \mu \mathrm{g} \cdot \mathrm{ml}^{-1}$ while P. stutzeri-CHP413A was also resistant to arsenite $\left(\mathrm{As}^{+3}\right)$. Microorganisms bind soluble heavy metals in three ways (biosorption, bioaccumulation, and the binding by metabolic products), which indirectly reduce the negative impact of heavy metals on plants $[28,29]$. Strain P. stutzeri-CHP413A was found to be resistant to chloramphenicol $(\mathrm{Cm})$ as well as ampicillin (Ap). All strains showed sensitivity against oxy-tetracycline (Tc), kanamycin (Kn), streptomycin (Sm), and erythromycin (E) but were resistant to chloramphenicol $(\mathrm{Cm})$. Strains $B$. frigoritolerans-LPS1B, B. subtilis-CHFT15, B. subtilisCHFT12, B. subtilis-CH13, and P. stutzeri-CHP413A were able to produce cytokinin but unable to produce indole acetic acid. The phytohormone cytokinin controls apical dominance and regulates root and shoot growth, leaf senescence, and chloroplast development [30]. P. stutzeriCHP413A showed maximum potential to produce $\mathrm{HCN}$, while B. subtilis-CH13 gave negative results in the case of $\mathrm{HCN}$ production. Recently, the beneficial role of $\mathrm{HCN}$ in the control of plant root-damaging subterranean termite has been studied [31]. Several investigators have shown that numerous soil bacteria - especially plant growth-promoting bacteria - can produce either cytokinins or gibberellins or both [32-34].

Maximum dry weight of EPS was $2.5 \mathrm{~g}$ and protein concentration was estimated $0.888 \mathrm{mg} / 10 \mathrm{mg}$ of EPS in the case of P. stutzeri-CHP413A. Several bacterial strains, especially Pseudomonas, survives under abiotic stress by 
producing exopolysaccharide [35]. Exopolysaccharide production has a great interest with respect to desiccation because rhizobacteria undergo adaptations. S. meliloti has shown adaption in the presence of exopolysaccharide under osmotic stress and also affects the survival rate during dry conditions [36, 37]. Mary et al. [38] observed a decrease in survival rate of rhizobia upon the addition of polysaccharides when dried at an $\mathrm{RH}$ of $>3 \%$, but survival rate increased to $3 \% \mathrm{RH}$. However, specific properties of polysaccharides have different effects on survival rate of microorganism in a desiccated environment [38]. Short exposure to intermediate water activity when the water content is detrimental for the cells leads to higher survival [ 39 , 40].

The inoculation of $P$. stutzeri-CHP413A resulted in 6 , $18,23,37$, and $100 \%$ increase in germination, number of leaves, shoot and root length, and dry weight g-1fresh weight in pure soil. The above-described several broad spectrum plant growth promoting attributes of selected rhizo-bacterial isolates, especially the strain P. stutzeriCHP413A, is likely to be the potential candidate for the enhancement of maize growth under drought and a desiccated environment.

\section{References}

1. BALSER T. C., KINZIG A. P., FIRESTONE M. K. Linking soil microbial communities and ecosystem functioning. In: KINZIG A. P., PACAL S. W., TILMAN D. (Eds). The Functional Consequences of Biodiversity: Empirical Progress and Theoretical Extensions, Princeton University Press, Princeton, NJ, pp. 265, 2001.

2. GLICK B. R., PENROSE D. M., LI J. A model for the lowering of plant ethylene concentrations by plant growth-promoting bacteria. J. Theor. Biol. 190, 63, 1998.

3. CHENG Z., PARK E., GLICK B. R. 1-Aminocyclopropape-1carboxylate deaminase from Pseudomonas putida UW4 facilitate the growth of canola in the presence of sat. Can. J. Microbiol. 53, 912, 2007.

4. PETTERSSON M. Factors affecting rate of change in soil bacterial communities. Doctoral thesis Lund University Gothorvm Caroline Sweden, 2004.

5. LIU L., KLOEPPER J. W., TUZUN S. Induction of systemic resistance in cucumber against bacterial angular leaf spot by plant growth-promoting rhizobacteria. Phytopathology. 85, 843,1995

6. ALI S., CHARLES T. C., GLICK B. R. Delay of flower senescence by bacterial endophytes expressing 1-aminocyclopropane-1-carboxylate deaminase. J. Appl. Microbiol. 113, 1365, 2012.

7. CHEN L., DODD I. C., THEOBALD J. C., BELIMOV A. A., DAVIES W. J. The rhizobacterium Variovorax paradoxus 5C-2 containing ACC deaminase promotes growth and development of Arabidopsis thaliana via an ethylenedependent pathway. J. Exp. Bot. 64, 1565, 2013.

8. GLICK B. R., PENROSE D. M., LI J. A model for the lowering of plant ethylene concentrations by plant growth-promoting bacteria. J. Theor. Biol. 190, 63, 1998.

9. ZAHIR A. Z., GHANI U., NAVEED M., NADEEM S. M., ASGHAR H. N. Comparative effectiveness of Pseudomonas and Serratia sp. containing ACC-deaminase for improving growth and yield of wheat (Triticum aestivum L.) under salts stressed conditions. Arch. Microbiol. 191, 415, 2009.

10. GRICHKO V. P., GLICK B. R. Amelioration of flooding stress by ACC deaminase containing plant growth-promoting bacteria. Plant Physiol. Biochem. 39, 11, 2001.

11. MAYAK S., TIROSH T., GLICK B. R. Plant growth-promoting bacteria that confer resistance to water stresses in tomato and pepper. Plant Sci. 166, 525, 2004.

12. YANG Z., WU Y. R., LI Y., LING H. Q., CHU C. C. OsMT1a a type 1 metallothionein plays the pivotal role in zinc homeostasis and drought tolerance in rice. Plant Mol. Biol. 70, 219, 2009.

13. KLOEPPER J., RYU C. M., ZHANG S. Induce systemic resistance and promotion of plant growth by Bacillus spp. Phytopathology. 94, 1259, 2004.

14. KODIKARA J., COSTA S. Desiccation Cracking in Clayey Soils: Mechanisms and Modelling In: LALOUI L., FERRARI A. (Eds) Multiphysical Testing of Soils and Shales. 21-32 Springer, Berlin, Heidelberg, pp. 21-32, 2013.

15. WANG X. Q., YANG P. F., LIU Z., LIU W. Z., HU Y., CHEN H., HE Y. K. Exploring the mechanism of Physcomitrella patens desiccation tolerance through a proteomic strategy. Plant Physiol. 149, 1739, 2009.

16. YILMAZ M., CELIK G. Y., ASLIM B., ONBASILI D. Influence of carbon sources on the production and characterization of the exopolysaccharide (EPS) by Bacillus sphaericus 7055 Strain. J. Polym. Environ. 20, 152, 2012.

17. BASHAN Y., HOLGUIN G., DE-BASHAN L. E. Azospirillum-plant relationships: physiological molecular agricultural and environmental advances. Can. J. Microbiol. 50, 521, 2004.

18. RODRÍGUEZ-SALAZAR J., SUÁREZ R., CABALLERO-MELLADO J., ITURRIAGA G. Trehalose accumulation in Azospirillum brasilense improves drought tolerance and biomass in maize plants. FEMS Microbiol. Lett. 296, 52, 2009.

19. DONATI A. J., LEE H. I., LEVEAU J. H. J., CHANG W. S. Effects of indole-3-acetic acid on the transcriptional activities and stress tolerance of Bradyrhizobium japonicum. PLOS ONE. 8, 76559, 2013.

20. SHAHZADI I., AHMED R., HASSAN A., SHAH M. M. Optimization of DNA extraction from seeds and fresh leaf tissues of wild marigold (Tagetes minuta) for polymerase chain reaction analysis. Genet. Mol. Res. 9, 386, 2010.

21. AKIYOSHI D. E., REGIER D. A., GORDON M. P. Cytokinin Production by Agrobacterium and Pseudomonas sp. J. Bacteriol. 169, 4242, 1987.

22. TANG W. Y., BORNER J. Enzymes involved in synthesis and breakdown of indoleacetic acid In: PAECH K., TRACEY M.V., (Eds) Modern Methods of Plant Analysis. Gohingen, Heidelberg, Springer Verlag, pp. 238-241, 1979.

23. LORCK H. Production of hydrocyanic acid by bacteria. Physiol. Plant. 1, 142, 1948.

24. AHMAD F., AHMAD I., KHAN M. S. Screening of freeliving rhizospheric bacteria for their multiple plant growth promoting activities. Microbiol. Res. 168, 173, 2008.

25. LOUDEN B. C., HAARMANN D., LYNNE A. Use of blue agar cas assay for siderophore detection. J. Microbiol. Biol. Educ. 12, 2011.

26. DUBOIS M., GILLES K., HAMILTON J., REBERS P., SMITH F. Colorimetric method for determination of sugars and related substances. Anal. Chem. 28, 350, 1956.

27. VERHOEF R. P. Structural characterization and enzymatic degradation of exopolysaccharides involved in paper mill 
slime deposition. Ph.D Thesis Wageningen University Netherlands, 2005.

28. TANGAHU B. V., ABDULLAH S. R. S., BASRI H., IDRIS M., ANUAR N., MUKHLISIN M. A review on heavy metals $(\mathrm{As}, \mathrm{Pb}$ and $\mathrm{Hg}$ ) uptake by plants through phytoremediation. Int. J. Chem. Eng. 2011, 939161, 2011.

29. RANGABHASHIYAM S., ANU N., SELVARAJU N. Biosorption of heavy metals using low cost agricultural by products. Res. J. Chem. Environ. 17, 112, 2013.

30. OLDROYD G. E. D. Nodules and Hormones. Plant Sci. 315, 52, 2007.

31. DEVI K. K., SETH N., KOTHAMASI S., KOTHAMASI D. Hydrogen cyanide-producing rhizobacteria kill subterranean termite Odontotermes obesus (rambur) by cyanide poisoning under in vitro conditions. Curr. Microbiol. 54, 74, 2007.

32. LORTEAU M. A., FERGUSON B. J., GUINEL F. C. Effects of cytokinin on ethylene production and nodulation in pea (Pisum sativum) cv Sparkle. Physiol. Plant. 112, 421, 2001.

33. KANG S. M., JOO G. J., HAMAYUN M., SHIN D. H., KIM H. Y., HONG J. K., LEE I. J. Gibberellin production and phosphate solubilization by newly isolated strain of Acinetobacter calcoaceticus and its effect on plant growth. Biotechnol. Lett. 31, 277, 2009.
34. KO K. W., OKADA K., KOGA J., JIKUMARU Y., NOJIRI H., YAMANE H. Effects of cytokinin on production of diterpenoid phytoalexins in rice. J. Pest. Sci. 35, 412, 2010.

35. SANDHYA V., ALI S. K. Z., GROVER M., REDDY G., VENKATESWARLU B. Alleviation of drought stress effects in sunflower seedlings by exopolysaccharide producing Pseudomonas putida strain P45. Biol. Fert. Soil 46, 17, 2009

36. BREEDVELD M. W., ZEVENHUIZEN L. P. T. M., ZEHNDER A. J. B. Osmotically induced oligo and polysaccharide synthesis by Rhizobium meliloti SU-47. J. Gen. Microbiol. 136, 2511, 1991.

37. LLORET J., WULFF B. B., RUBIO J. M., DOWNIE J. A., BONILLA I., RIVILLA R. Exopolysaccharide II production is regulated by salt in the halotolerant strain Rhizobium meliloti EFB1. Appl. Environ. Microbiol. 64, 1024, 1998.

38. MAH T. F., PITTS B., PELLOCK B., WALKER G. C., STEWART P. S., O'TOOLE G. A. A genetic basis for Pseudomonas aeruginosa biofilm antibiotic resistance. Nature 426, 306, 2003.

39. POTTS M. Desiccation tolerance of prokaryotes. Microbiol. Rev. 58, 755, 1994.

40. RINAUDO M. Role of substituents on the properties of some polysaccharides. Biomacromolecules. 5, 1155, 2004. 
